Jurnal Adat dan Budaya, Vol.1, No.2 Tahun 2019

ISSN: E-ISSN 2615-6156, P-ISSN: 2615-6113

Jurnal Homepage: https://ejournal.undiksha.ac.id/index.php/JABI/index

\title{
Model Pembelajaran VAK Berbasis Tri Kaya Parisudha Berpengaruh Terhadap Kompetensi Pengetahuan IPA Kelas V
}

\author{
Ni Kadek Utari Widyastuti1. Ni Wayan Suniasih² \\ ${ }^{12}$ Jurusan Pendidikan Dasar, Universitas Pendidikan Ganesha, Bali, Indonesia \\ E-mail: kadekutariwid@gmail.com
}

\begin{abstract}
Abstrak
Dari hasil observasi kompetensi pengetahuan IPA siswa kelas V masih belum optimal. Penggunaan model pembelajaran pun terbilang belum bervariasi khususnya model pembelajaran VAK berbasis Tri Kaya Parisudha. Sehingga tujuan dilaksanakan penelitian ini untuk mengetahui pengaruh model pembelajaran VAK berbasis Tri Kaya Parisudha terhadap kompetensi pengetahuan IPA kelas V. Termasuk kedalam penelitian eksperimen semu dengan tipe rancangan The Posttest Only No-Treatment Kontrol Group Design. Keseluruhan kelas V yang bersangkutan menjadi anggota populasi sebanyak 227 peserta didik. Penentuan sampel menggunakan teknik classter random sampling, selanjutnya dipilih 2 anggota populasi untuk menjadi sampel penelitian yang terbagi menjadi kelompok eksperimen dan kelompok kontrol. Data kompetensi pengetahuan IPA dikumpulkan menggunakan metode tes berupa instrument tes objektif pilihan ganda sebanyak 30 soal yang sudah tervalidasi. Data dianalisis menggunakan uji beda mean yang menunjukan hasil nilai $t_{\text {hitung }}=5,803>t_{\text {tabel }}=1,991$ pada taraf signifikansi $5 \%(\alpha=0,05, \mathrm{dk}=76)$ sehingga $\mathrm{H}_{0}$ ditolak dan $\mathrm{H}_{\mathrm{a}}$ diterima. Sesuai hasil tersebut dapat disimpulkan model pembelajaran VAK berbasis Tri Kaya Parisudha berpengaruh signifikan terhadap kompetensi pengetahuan IPA kelas V. Hasil penelitian ini dijadikan sebagai alternatif bagi guru dalam memilih model pembelajaran yang tepat, sehingga membantu siswa mencapai kompetensi pengetahuan dengan cemerlang.
\end{abstract}

Kata Kunci: VAK; Tri Kaya Parisudha; Kompetensi Pengetahuan IPA

\begin{abstract}
From the results of observations of science competence, science students in class V are still not optimal. The use of learning models also has not been varied, especially the VAK learning model based on Parisian Rich Rich. So the purpose of this research is to find out the effect of Tri Rich Parisudha-based VAK learning model on the science competency of Class $\mathrm{V}$ science. Included in this research is quasi-experimental research with the design type of The Posttest Only No-Treatment Control Group Design. Overall class V concerned is a member of a population of 227 students. Determination of the sample using the technique of classter random sampling, then 2 members of the population were selected to be the research sample divided into the experimental and control groups. Science knowledge competency data was collected using a test method in the form of multiple choice objective test instruments of 30 questions that have been validated. Data were analyzed using the mean difference test which showed the results of tcount $=5.803>$ ttable $=1.991$ at a significance level of $5 \%(\alpha=0.05, \mathrm{dk}=76)$ so that $\mathrm{HO}$ was rejected and Ha was accepted. Based on these results it can be concluded that the VAK learning model based on Tri Rich Parisudha has a significant effect on the knowledge competency of the fifth grade science.
\end{abstract}

Keywords: VAK; Tri Kaya Parisudha; Kompetensi Pengetahuan IPA

\section{PENDAHULUAN}

Salah satu jenjang pendidikan yang harus diikuti oleh anak adalah pelatihan di Sekolah Dasar (SD). Di sekolah siswa mengikuti proses belajar yang dirancang oleh guru. Berhasil tidaknya suatu pembelajaran dipengaruhi oleh kompenen yang saling terkait diantaranya yaitu, kompenen tujuan, bahan pelajaran, metode, media, model pembelajaran, sarana prasarana, siswa dan guru. Atmaja (2019) Guru memegang peranan penting dalam aktivitas belajar siswa. Diakhir proses pembelajaran, siswa tentu mendapatkan hasil belajar. Hasil belajar yang diperoleh dipengaruhi baik dari kemampuan siswa ataupun bersumber dari lingkungan. Pramita (2018) kemungkinan yang dapat mempengaruhi hasil belajar yaitu cara guru merancang kegiatan pembelajaran. Ambarawati (2020) Kesuksesan guru melahirkan anak bangsa yang berkompeten diawali dari pemilihan model pembelajaran yang digunakan. Proses belajar yang baik akan membantu siswa dalam memahami kompetensi tertentu, begitu pula sebaliknya pembelajaran yang kurang baik akan berdampak pada kurangnya pemahaman siswa terhadap kompetensi pengetahuan yang ingin dicapai. 
Meningkatkan kualitas pendidikan menjadi pekerjaan yang tidak mudah. Rani (2019) Pemerintah sudah berupaya semaksimal mungkin yaitu, dengan meningkatkan sarana prasarana dalam dunia pendidikan dan menyusun serta menyempurnakan kurikulum. Saat ini proses pembelajaran di SD menggunakan kurikulum 2013 yang pada pembelajarannya lebih berpusat pada siswa dengan pembelajaran tematik terpadu. Melalui lima pengalaman belajar sesuai kurikulum 2013, siswa diminta lebih proaktif, kreatif dan menggali pengetahuannya sendiri. Urmila (2019) Bahan ajar untuk kegiatan belajar di SD diambil dari beberapa mata pelajaran. IPA menjadi mata pelajaran wajib yang dipelajari oleh siswa SD. Primayonita (2020) Dalam rangka mempersiapkan sumber daya manusia yang berkualitas mempelajari IPA menjadi hal yang utama. Febbriana (2019) IPA ialah rumpun pengetahuan yang terstruktur dalam mempelajari gejala alam semesta lewat observasi. Pendidikan IPA mengasah kemahiran siswa belajar mengenai makrokosmos beserta isinya, melalui pengamatan dan prosedur yang sistematis (Samatowa, 2016). Cantona (2020) IPA dapat mengelaborasi kecakapan peserta didik agar mampu membentuk konsepsi secara independen dan sangat dinamis untuk siswa mengenal dirinya sendiri serta apa saja yang terjadi di alam. Paramita (2020) aspek pokok dalam belajar IPA adalah membangkitkan sikap ilmiah anak secara rasional serta mampu mengaitkannya dalam kehidupan nyata. Krismayoni (2020) IPA wajib diperhitungkan sebagai cara berpikir untuk menginterpresentasikan alam melalui investigasi. Dewi (2018) Kompetensi pengetahuan IPA adalah modifikasi sikap anak selepas menjejaki proses belajar yang meliputi jenjang berpikir dalam memahami lingkungan melalui pengamatan. Yudiana (2020) Kompetensi Pengetahuan IPA ialah aktivitas guru dalam pemberian nilai terhadap kecakapan siswa setelah mengikuti proses belajar IPA.

Pada kenyataanya, berdasarkan hasil pengamatan di Gugus VI Kecamatan Sukawati Tahun Ajaran 2019/2020, nilai yang dicapai oleh siswa sebagian besar khususnya dalam pelajaran IPA masih kurang. Ini disebabkan karena muatan materi IPA masih menjadi pembelajaran yang membosankan bagi siswa, selain itu sudah tertanam dalam pola pikiran siswa bahwa muatan materi IPA harus dihapalkan, tanpa diminta mencari tahu mengenai hubungan pengetahuan yang didapatkannya dengan situasi nyata. Dalam mencari informasi pada saat kegiatan mengamati objek, murid masih kurang teliti. Ketika dilakukan sebuah percobaan siswa terlihat kurang konsentrasi dan masih asik bermain dengan teman-temannya. Dalam mengkomunikasikan hasil percobaan, teramati siswa masih kurang tenang dan percaya diri. Saat merasa kesulitan atau kebingungan dalam memahami materi IPA sebagian peserta didik merasa canggung menanyakan secara langsung pada guru. Saat kegiatan diskusi, hanya beberapa anak didik saja terlibat aktif menjawab ataupun bertanya. Merumuskan pertanyaan akan membantu siswa dalam membentuk pikiran yang kritis dan mengembangkan rasa ingin tahu siswa. Peserta didik merasa cepat jenuh serta partisipasinya masih kurang saat proses pembelajaran berlangsung. Berdasarkan beberapa hasil penelitian juga menunjukan hal yang sama, seperti yang dilakukan oleh Widiastiti (2020) Rendahnya persentase nilai IPA siswa yakni 38,95\% melampaui kkm dan 61,04\% tidak melapaui kkm. Putri (2019) hasil kompetensi pengetahuan IPA dari 334 siswa diperoleh 148 siswa atau sekitar 44,32\% yang belum mencapai KKM. Variani (2020) Nilai UTS IPA menunjukan sebanyak 69 peserta didik mendapatkan nilai dibawah re-rata dari 113 siswa. Arisantiani (2018) menyatakan bahwa rata-rata nilai akhir kompetensi pengetahuan IPA siswa kurang optimal yakni di bawah nilai KKM, siswa dikatakan tuntas apabila memenuhi nilai KKM sekitar 68,00. Septiawan (2020) saat siswa berproses seringkali guru tidak melibatkannya, sehingga hasil belajar dirasa belum optimal. Dari paparan tersebut, ditemukan kesenjangan pada muatan materi IPA sesuai kurikulum 2013 ditetapkan kriteria ketuntasan minimalnya B-, akan tetapi kenyataanya masih ada peserta didik yang memperoleh nilai dibawah B-. Padahal, belajar IPA bisa menjadi wadah untuk memperdalam keterampilan siswa dalam menyesuaikan diri dengan perubahan yang ada. Anak yang mempelajari IPA sejak dini akan diuntungkan, apalagi dalam persaingan hidup yang semakin kompetitif, niscaya mereka akan melek sains, sehingga mampu memilah informasi, menentukan keputusan yang cermat dan dapat mengembangkan sikap-sikap ilmiah yang dimilikinya. Raharja (2019) dalam pembelajaran IPA, rasa ingin tahu siswa pun akan muncul secara alamiah yang melatih cara mengungkapan pendapat ataupun bertanya dengan logis.

Salah satu cara menciptakan suasana belajar IPA yang aktif dengan merancang suatu pembelaajaran. Triyana (2020) merancang suatu pembelajaran tentu melibatkan beberapa komponen yang saling terikat seperti, bahan ajar, media, strategi, model pembelajaran dan yang lainnya. Lestari (2018) Upaya untuk membangun antusiasme siswa dalam belajar materi IPA yakni dengan kreattifitas guru memodifikasi desain pembelajaran. Pernyataan tersebut didukung oleh Gosachi (2020) siasat untuk menanggulangi persoalan dalam pembelajaran yakni menerapkan model pembelajaran yang cermat. Model pembelajaran VAK (Visual, Autidory dan Kinestethic) menjadi salah satu alternatifnya, 
karena mengajak siswa untuk berproses bersama. Model VAK mementingkan profesionalisme cara belajar secara serentak dengan visual, auditory dan kinestethic yang dimilikinya untuk mencapai pemahaman dan berpendirian mewujudkan kondisi belajar yang nyaman dan menjamin kecemerlangan bagi pembelajaran (De Porter 2015). Secara teoretis model ini memiliki kelebihan, yakni (1) pembelajaran berjalan dengan efisien karena memadukan tiga gaya belajar, (2) memberikan pengalaman belajar, (3) mampu menjangkau setiap cara belajar siswa dan (4) mengimplikasikan anak didik secara optimal dalam menginterpretasikan suatu konsepsi melalui aksi fisik, seperti penyelidikan, diskusi aktif, percobaan dan demonstrasi (Shoimin, 2016). Kelebihan yang dimiliki oleh model pembelajaran VAK tentu memberikan keleluasaan kepada anak didik dalam mencerna muatan materi IPA, sehingga diharapkan memberikan dampak positif terhadap kompetensi pengetahuan IPA siswa. Mengkombinasikan ketiga gaya belajar ini memberikan kemudahan bagi siswa untuk menyeleksi informasi yang diperolehnya. Hampir semua orang memiliki ke tiga modalitas tersebut akan tetapi condong pada satu keahlian saja. Ada tiga gaya belajar yang ada pada anak, yakni: (1) visual: modalitas visual adalah gaya belajar siswa dengan menggunakan pengeliatan panca inderanya. Siswa yang mempunyai modalitas ini biasanya berbicara dengan cepat. (2) audiotory: modalitas anak didik yang menggunakan pendengarannya dalam memproses segala data yang diperoleh dari kegiatan belajar. (3) kinestetik: modalitas kinestetik adalah siswa yang dalam proses pembelajaran mendominasi segala bentuk gerak gerik dan perasaannya. (Huda, (2015). Elisa (2019, Vol 11) Timbul rasa percaya diri siswa apabila terpenuhi setiap kebutuhannya, sehingga proses pembelajaran menjadi lebih bernilai. Adnyani (2020) model vak membebaskan anak menggunakan modalitasnya belajar secara langsung untuk mencapai pemahaman sehingga tercipta suasana belajar yang nyaman. Rukmana (2018) Gaya belajar vak memaksimalkan fungsi system indra manusia seperti mata, telinga dan sentuhan yang akan dikembangkan, sehingga menciptakan suasana belajar efektif dan menyenangkan.

Dalam penerapan model pembelajaran VAK dipadukan dengan ajaran Tri Kaya Parisudha yang secara teoretik mampu menunjang tercapainya kompetensi pengetahuan IPA, Sri (2018, Vol 14). Tri Kaya Parisudha artinya tiga sikap manusia yang harmonis dan dijadikan pegangan hidup oleh setiap umat Hindu yang saling berkaitan satu sama lain (Singer, 2017). Rancangan pengetahuan IPA yang layak dipahami secara nyata dan konseptual melalui bernalar, berucap dan bertindak yang baik. Dalam mengajarkan IPA harus diawali dengan pikiran yang terfokus, sehingga dapat menalarkan serta mencermati pengetahuan yang d pelajari dengan benar, gerakan ini disebut dengan manacika parisudha. Pengetahuan yang disimpan dalam pola pikirannya kemudian patut untuk disuarakan pada saat persentasi maupun diskusi dengan berbicara yang sopan atau disebut wacika parisudha. Kegiatan pada saat belajar IPA adalah praktek mengenai definisi konsep, saat anak didik melakukan berbagai percobaan ia harus menunjukan gerak gerik yang tertib dan bertanggung jawab tindakan ini dikenal sebagai kayika parisudha.

Tujuan yang ingin dicapai dalam penelitian ini yaitu untuk mengetahui pengaruh model pembelajaran VAK Berbasis Tri Kaya Parisudha terhadap kompetensi pengetahuan IPA kelas V SD Gugus VI Kecamatan Sukawati Gianyar Tahun Ajaran 2019/2020.

\section{METODE}

Jenis penelitian yakni termasuk penelitian eksperimen dengan desain quasi exsperimental dan rancangan tipe The Posttest Only No-Treatment Kontrol Group Design. Tipe design ini hanya memanfaatkan post-test dalam mengukur kompetensi pengetahuan IPA sesudah menerima perlakuan (Thyer B, 2012). Memperturutkan dua kelompok kelas yaitu kelompok eksperimen dan kelompok kontrol. Dapat dikatakan pada design ini yang menjadi fokus utama penelitian adalah kelompok eskperimen. Populasi penelitian yakni semua kelas V SD Gugus VI Kecamatan Sukawati Tahun Ajaran 2019/2020, dengan jumlah 227 peserta didik. Dari informasi Kepala Sekolah dan Guru kelas V di masing-masing SD menyatakan bahwa kelas V di Gugus VI Kecamatan Sukawati setara secara akademik, jadi tidak ada kelas favorit.

Ada 3 tahapan dalam penelitian ini yaitu (1) tahap persiapan, kegiatan yang dilakukan ialah: wawancara dengan kepala sekolah dan beberapa wali kelas V di Gugus bersangkutan, membicarakan tema dan materi yang diuji cobakan bersama wali kelas, menyusun RPP yang digunakan untuk membelajarkan kelompok eksperimen, mengkonsultasikan RPP dan Instrumen penelitian bersama dosen pembimbing dan wali kelas, meminta data terkait nilai ulangan akhir semester tahun 2019/2020 
pada mata pelajaran IPA yang akan dianalisis datanya menggunkan uji-t untuk penyetraan, melaksanakan pengundian untuk menentukan status sampel. (2) Tahap pelaksanaan, aktivitas yang dilakukan meliputi: memberikan treatment bagi kelompok eksperimen berupa model VAK berbasis Tri Kaya Parisudha dan belajar menggunakan pendekatan saintifik pada kelompok kontrol, perlakuan diberikan sebanyak 6 kali di kelompok eksperimen dan melangsungkan uji coba instrument penelitian soal post test. (3) Tahap Akhir eksperimen, yaitu: memberikan post test untuk kedua kelompok, menelaah data hasil penelitian dan melakukan uji hipotesis.

Penentuan sampel menggunakan teknik classterrandom sampling. Pemilihan sampel dilaksanakan secara random, hal pertama yang dilalui yaitu menuliskan seluruh nama populasi pada selembar kertas, kertas selanjutnya diremas-remas ditaruh di atas meja, kemudian diambil 2 kertas untuk menentukan sekolah yang dijadikan sampel. Sampel yang mewakili populasi yakni kelas V SDN 2 Batubulan dan kelas V SDN 7 Batubulan. Kedua sekolah kemudian dilakukan uji kesetaraan terlebih dahulu, dengan mengkaji nilai UAS IPA menggunakan uji-t. Kesimpulan dari hasil uji prasyarat analisis yakni, sampel penelitian memiliki sebaran data yang berdistribusi normal dan varian yang homogen. Sehingga, uji kesetaraan sampel menggunakan uji beda mean dengan rumus polled varian bisa dilaksanakan. Diperoleh harga $\mathrm{t}_{\text {hitung }}=0,387<\mathrm{t}_{\text {tabel }}=1,991$ maka $\mathrm{H}_{0}$ diterima dan sampel diakui setara. Selanjutnya dilakukan pengundian kembali dalam menetapkan status sekolah, yaitu Kelas V SDN 2 Batubulan ditetapkan sebagai kelompok eksperimen yang diberi treatment dan kelas V SDN 7 Batubulan ditetapkan sebagai kelompok kontrol yang dibelajarkan menggunakan pembelajaran seperti biasa. Terdapat 2 variabel pada penelitian yaitu variabel bebas (model pembelajaran VAK Berbasis Tri Kaya Parisudha) dan variabel terikat (kompetensi pengetahuan IPA).

Data yang dianalisis yaitu mengenai kompetensi pengetahuan IPA yang dikumpulkan melalui tes. Metode tes dipakai dalam mengakumulasi data penelitian, dengan jenis tes objektif pilihan ganda biasa yang berisi empat opsi dan mengandung satu jawaban akurat. Data terkait kompetensi pengetahuan IPA dikumpulkan menggunakan tes, sehingga diperoleh data berupa skor yang berskala interval. Data yang diukur ialah terkait kompetensi pengetahuan IPA yang mengidentifikasi panas dan perpindahannya dalam kehidupan sehari-hari. Indikator digunakan sebagai barometer penilaian dan butir tes yang dibuat berdasarkan indikator yang telah ditetapkan. Indikator biasanya terdapat di dalam kisi-kisi soal yang berisikan juga KD dan materi pembelajaran yang dibuat dalam bentuk matriks. Terdapat 8 indikator yang harus dicapai siswa meliputi 1 indikator pada C1 (mengamati), 2 indikator pada C2 (memahami), 3 indikator pada C3 (menerapkan) dan 2 indikator pada C4 (menganalisis). Jumlah soal secara keseluruhan yaitu sebanyak 30 butir soal. Kisi-kisi instrument lebih lanjut dijelaskan pada tabel berikut.

Tabel 1. Kisi-kisi Instrumen Tes Kompetensi Pengetahuan IPA

\begin{tabular}{|c|c|c|c|c|c|c|c|c|}
\hline \multirow[t]{2}{*}{$\begin{array}{l}\text { Kompetensi } \\
\text { Dasar }\end{array}$} & \multirow[t]{2}{*}{ Indikator } & \multicolumn{4}{|c|}{$\begin{array}{l}\text { Tingkat } \\
\text { Kognitif }\end{array}$} & \multirow[t]{2}{*}{$\begin{array}{l}\text { Bentu } \\
\text { k Soal }\end{array}$} & \multirow[t]{2}{*}{$\begin{array}{l}\text { Nomor } \\
\text { Soal }\end{array}$} & \multirow{2}{*}{$\begin{array}{c}\text { Juml } \\
\text { ah } \\
\text { Soal }\end{array}$} \\
\hline & & $\begin{array}{l}\mathrm{C} \\
1\end{array}$ & $\begin{array}{l}\mathrm{C} \\
2\end{array}$ & $\begin{array}{l}\mathrm{C} \\
3\end{array}$ & $\begin{array}{l}\mathrm{C} \\
4\end{array}$ & & & \\
\hline \multirow{5}{*}{$\begin{array}{l}3.7 .6 \\
\text { Menerapkan } \\
\text { konsep } \\
\text { perpindahan } \\
\text { kalor dalam } \\
\text { kehidupan } \\
\text { sehari-hari }\end{array}$} & $\begin{array}{l}\text { 3.7.1 Mengidentifikasi } \\
\text { manfaat energy panas dan } \\
\text { benda-benda yang dapat } \\
\text { menghantarkan panas }\end{array}$ & $\checkmark$ & & & & PGB & $\begin{array}{l}2,6,8 \\
10\end{array}$ & 4 \\
\hline & $\begin{array}{lr}3.7 .2 & \text { Menjabarkan } \\
\text { mengenai } & \text { sumber energi } \\
\text { panas } & \end{array}$ & & $\checkmark$ & & & PGB & $1,3,5,7$ & 4 \\
\hline & $\begin{array}{l}\text { 3.7.3 Membandingkan } \\
\text { perbedaan suhu dan panas }\end{array}$ & & $\checkmark$ & & & PGB & $\begin{array}{l}4,9,14 \\
18\end{array}$ & 4 \\
\hline & $\begin{array}{l}\text { 3.7.4 Mengklasifikasi cara } \\
\text { dan peristiwa perpindahan } \\
\text { kalor secara konduksi }\end{array}$ & & & $\checkmark$ & & PGB & $\begin{array}{l}15,22 \\
27\end{array}$ & 3 \\
\hline & $\begin{array}{l}\text { 3.7.5 Menentukan cara dan } \\
\text { peristiwa perpindahan } \\
\text { kalor secara konveksi }\end{array}$ & & & $\checkmark$ & & PGB & $\begin{array}{l}11,23 \\
24,30\end{array}$ & 4 \\
\hline
\end{tabular}


Jurnal Adat dan Budaya Vol. 1, No. 2, Tahun 2019, pp. 45-53

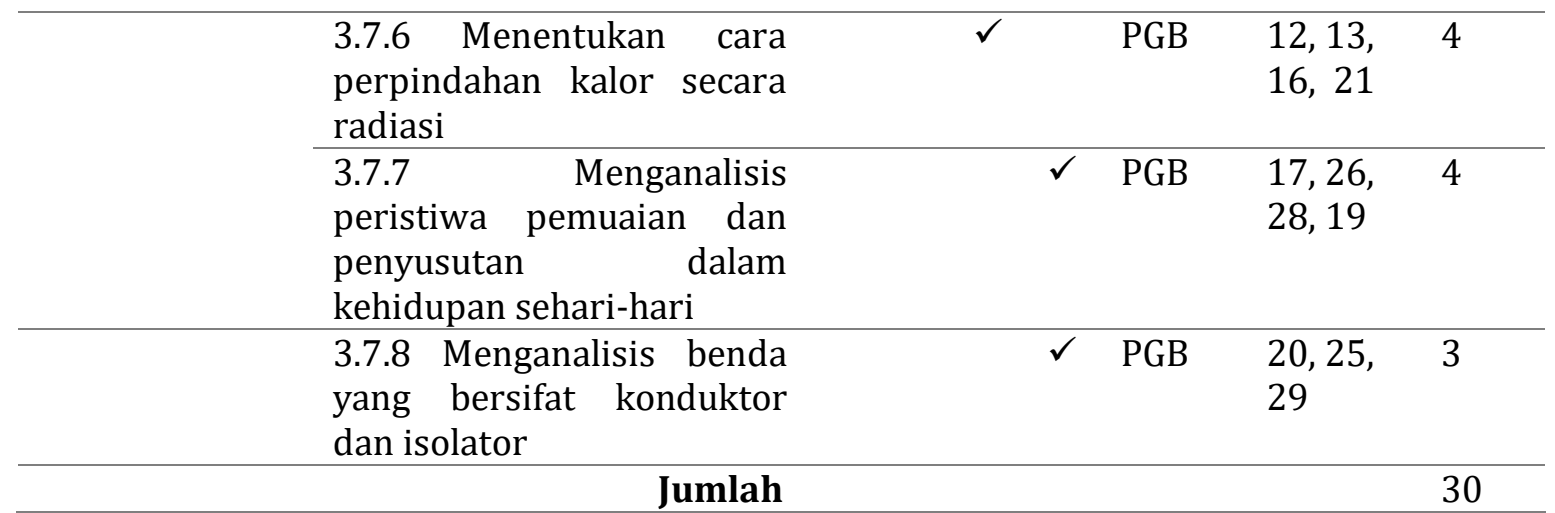

Tes yang digunakan sudah diuji kelayakannya dengan melakukan validasi instrument, melalui 1) Uji Validitas terdiri dari validitas isi yang berhubungan dengan ketepatan alat penilaian dalam menghitung variabel yang mau diukur berkenaan dari segi isinya dan validitas butir soal ialah aktivitas menjabarkan kualitas baik buruknya unsur-unsur soal pada tes menggunakan rumus korelasi product moment, dengan kategori apabila $r_{\text {hit }}>r_{\text {tab }}$ dikatakan valid, jika $t_{\text {hit }}<r_{\text {tab }}$ dinyatakan tidak valid. Dari 40 soal yang diujikan didapat 30 soal yang valid. 2) Uji Reliabilitas, berdasarkan hasil perhitungan menggunakan rumus Kuder Richardson 20, diperoleh nilai $r_{11}$ sebesar 0,88, sehingga tes kompetensi pengetahuan IPA memiliki kriteria reliabilitas sangat tinggi. 3) Uji Daya Beda, tes yang diujikan pada tahap ini ialah tes yang valid saja, rekapitulasi hasil uji daya beda diperoleh 3 soal jelek, 11 soal cukup, 15 soal baik dan 1 soal sangat baik. 4) Uji Tingkat Kesukaran dengan hasil 19 soal mudah, 9 soal sedang dan 2 soal sukar.

Metode analisis statistik yang dipergunakan saat mengolah data hasil penelitian yakni statistik inferensia. Statistik ini berkorelasi dengan analisis data, biasanya statistic inferensial dipergunakan untuk menganalisis data sampel dan hasil analisisnya dapat menyelidiki keseluruhan data. Sebelum dianalisis dat di uji prasyarat analisisnya pada taraf signifikansi 5\% sebagai berikut, 1) uji normalitas sebaran data dengan uji Kolmogorov-smirnov, kriteria pengujiannya apabila $\mathrm{KS}_{\text {hit }} \leq \mathrm{KS}_{\text {tab }}$ maka data dikatakan berdistribusi normal. 2) uji homogenitas varian dengan uji fisher (Uji F), kriteria pengujian jika Fhit $\leq$ Ftab, maka data mempunyai varians yang homogen. Bila sudah memenuhi uji prasyarat, selanjutnya melakukan pengujian hipotesis menggunakan uji-t, rumus polled varian dengan kriteria pengujian apabila $t_{\text {hit }} \leq \mathrm{t}_{\text {tab }}$ maka Ho ditolak (gagal diterima).

\section{Hasil dan Pembahasan Hasil}

Selama proses penelitian berlangsung, secara umum pembelajaran terlaksana dengan baik sesuai dengan rancangan model pembelajaran VAK berbasis Tri Kaya Parisudha. Data yang diperoleh dalam penelitian ini yakitu data kompetensi pengetahuan IPA kelas V SDN Gugus VI Kecamatan Sukawati Tahun Ajaran 2019/2020. Data pada penelitian ini digolongkan menjadi dua yaitu data kompetensi pengetahuan IPA kelompok eksperimen di SDN 2 Batubulan dan data kompetensi pengetahuan IPA kelompok kontrol di SDN 7 Babtubulan. Deskripsi data yang dijabarkan dalam penelitian ini diperoleh dari hasil posttest dari kedua kelompok.

Data pada kelompok eksperimen yang mendapatkan perlakuan sebanyak enam kali berupa penerapan model pembelajaran VAK berbasis Tri Kaya Parisudha dan kemudian diberikan posttest memperoleh skor maksimum 96 dan skor minimum 70. Hasil perhitungan distribusi frekuensi relatif, disajikan pada tabel berikut.

Tabel 2. Distribusi Frekuensi Relatif Kelompok Eksperimen

\begin{tabular}{|c|c|c|c|c|c|}
\hline Kelas Interval & $x_{i}$ & $f_{i}$ & $\mathbf{F k}$ & $f_{i} X_{i}$ & $F_{i}$ Relatif (\%) \\
\hline $70-74$ & 72 & 9 & 9 & 648 & 22,5 \\
\hline $75-79$ & 77 & 2 & 11 & 154 & 5 \\
\hline $80-84$ & 82 & 15 & 26 & 1230 & 37,5 \\
\hline $85-89$ & 87 & 5 & 31 & 435 & 12,5 \\
\hline $90-94$ & 92 & 8 & 39 & 736 & 20 \\
\hline $95-99$ & 97 & 1 & 40 & 97 & 2,5 \\
\hline
\end{tabular}




$\begin{array}{llll}\text { Jumlah } & 40 & 3300 & 100\end{array}$

Nilai rata-rata kompetensi pengetahuan IPA kelompok eksperimen yaitu 81,83, nilai ini kemudian dikonversikan ke dalam penerapan PAP skala lima berada pada kategori A dengan predikat Sangat Baik.

Selanjutnya, data kompetensi pengetahuan IPA pada kelompok kontrol yang dibelajarkan secara konvensional selanjutnya diberikan posttest mendapatkan skor maksimum 83 dan skor minimum 56. Rekapitulasi perhitungan distribusi frekuensi relatif, dipaparkan pada tabel berikut.

\section{Tabel 3. Distribusi Frekuensi Relatif Kelompok Kontrol}

\begin{tabular}{llllll}
\hline Kelas Interval & $\boldsymbol{x}_{\boldsymbol{i}}$ & $\mathbf{f}_{\mathbf{i}}$ & $\mathbf{F k}$ & $\mathbf{f}_{\mathbf{i}} \boldsymbol{x}_{\mathbf{i}}$ & $\mathbf{f}_{\mathbf{i}}$ Relatif (\%) \\
\hline $56-60$ & 58 & 4 & 4 & 232 & 10,52 \\
\hline $61-65$ & 63 & 2 & 6 & 126 & 5,26 \\
\hline $66-70$ & 68 & 10 & 16 & 680 & 26,31 \\
\hline $71-75$ & 73 & 7 & 23 & 511 & 18,42 \\
\hline $76-80$ & 78 & 12 & 35 & 936 & 31,58 \\
\hline $81-85$ & 83 & 3 & 38 & 249 & 7,90 \\
\hline Jumlah & & $\mathbf{3 8}$ & & $\mathbf{2 7 3 4}$ & $\mathbf{1 0 0}$
\end{tabular}

Nilai rata-rata kompetensi pengetahuan IPA yang diperoleh kelompok kontrol yaitu 72,37, nilai ini kemudian dikonversikan ke dalam penerapan PAP skala lima berada pada ketegori $\mathrm{C}$ dengan predikat Cukup.

Penelitian ini mengimplementasikan uji t dengan rumus polled varians untuk menguji hipotesis penelitian. Namun terlebih dahulu di uji homogenitas sebaran data dan uji homogenitas varian sebagai prasyarat analisis. Uji normalitas berfungsi untuk mengetahui apakah sebaran data skor pada kedua kelompok berdistribusi normal atau tidak. Rumus yang dipergunakan yakni Kolmogorov Smirnov, pada kelas eksperimen diperoleh skor maksimum $\left|\mathrm{F}_{\mathrm{T}}-\mathrm{F}_{\mathrm{S}}\right|=$ 0,107 dan skor tabel Kolmogorov-Smirnov dengan taraf signifikansi $5 \%=0,189$, karena skor maksimum $\left|\mathrm{F}_{\mathrm{T}}-\mathrm{F}_{\mathrm{S}}\right|<$ skor tabel Kolmogorov-Smirnov maka data berdistribusi normal. Pada kelas kontrol diperoleh skor maksimum $\left|F_{T}-F_{S}\right|=0,130$ dan skor tabel Kolmogorov-Smirnov untuk taraf signifikansi $5 \%=\mathrm{m} 0,194$, karena skor maksimum $\left|\mathrm{F}_{\mathrm{T}}-\mathrm{F}_{\mathrm{S}}\right|<$ skor tabel Kolmogorov-Smirnov maka data dikategorikan normal. Selanjutnya, dilakukan pengujian homogenitas varian antar kedua kelompok yang bertujuan untuk meyakinkan memang adanya perbedaan antar kelompok bukan karena di dalam kelompok itu perbedaan, menggunakan uji F dengan taraf signifikansi $5 \%$ dengan $\mathrm{dk}$ untuk pembilang masing-masing $\mathrm{n}-1$, rekapitulasi perhitungannya bahwa $\mathrm{F}_{\text {hit }}=0,87 \mathrm{dan}$ $\mathrm{F}_{\mathrm{tab}}=1,72$, pada tingkat signifikansi $5 \%$ dengan dk pembilang $=37 \mathrm{dan} \mathrm{dk}$ penyebut $=39$. Karena harga $\mathrm{F}_{\text {hit }} \leq \mathrm{F}_{\mathrm{tab}}$, maka data memiliki varian yang homogeny.

Setelah melewati uji prasyarat analisis, diketahui sebaran data kedua kelompok normal dan mempunyai varian yang homogen, sehingga uji hipotesis dengan uji beda mean tipe polled varinas dapat dilakukan. Kriteri pengujian apabila $t_{\text {hit }}<t_{\text {tab }}$ maka $H_{0}$ diterima dengan $d k=n 1+n 2-2$ pada taraf signifikan $5 \%$. Hasil pengujiannya disajikan pada tabel berikut.

Tabel 4. Rekapitulasi Hasil Pengujian Hipotesisl Uji-t

\begin{tabular}{|c|c|c|c|c|c|c|c|c|}
\hline No & Sampel & $\mathbf{N}$ & Dk & $\mathbf{X}$ & $\mathbf{S}^{2}$ & $t_{\text {hitung }}$ & $t_{\text {tabel }}$ & keterangan \\
\hline 1. & $\begin{array}{c}\text { Kelas } \\
\text { Eksperimen }\end{array}$ & 40 & 76 & 81,83 & 55,64 & 5,803 & 1,991 & H0 ditolak \\
\hline 2. & $\begin{array}{c}\text { Kelas } \\
\text { Kontrol }\end{array}$ & 38 & & 72,37 & 48,62 & & & \\
\hline
\end{tabular}

Berdasarkan hasil analisis diperoleh harga $t_{\text {hitung }}=5,803$ harga ini kemudian dibandingkan dengan harga $t_{\text {tabel }}$ pada taraf signifikansi $5 \%$ dengan dk $(40+38-2=76)$ diperoleh harga $t_{\text {tabel }}=1,991$. Dikarenakan, harga $t_{\text {hitung }}>t_{\text {tabel, }}$, dengan demikian $\mathrm{H}_{0}$ ditolak (gagal diterima). Hasil ini memiliki arti bahwa terdapat perbedaan yang signifikan kompetensi pengetahuan IPA antara kelompok eksperimen dan kelompok kontrol pada kelas V SDN Gugus VI Kecamatan Sukawati Tahun Ajaran 2019/2020. Hal ini terjadi karena memberikan treatmen yang berbeda kepada kedua kelompok. 
Dari perhitungan hasil analisis diperoleh rerata kompetensi pengetahuan IPA kelompok eksperimen adalah 81,83 lebih besar dari kompetensi pengetahuan IPA kelompok kontrol yakni 72,37. Oleh sebab itu, dalam penelitian ini telah dibuktikan secara empiris bahwa terdapat perbedaan kompetensi pengetahuan IPA yang dibelajarkan menggunakan model pembelajaran VAK berbasis Tri Kaya Parisudha dengan kompetensi pengetahuan IPA yang diajarkan secara konvensional. Dalam kateori pun kelas eksperimen termasuk kedalam kategori Sangat Baik dan kelas kontrol dikategorikan Cukup.

Perbedaan hasil yang didapat antara kedua kelomopok disebabkan oleh perbedaan perlakuan yang diberikan. Terlihat hasil rata-rata kelompok eskperimen lebih tinggi dikarenakan treatmen model pembelajaran VAK berbasisi Tri Kaya Parisudha berjalan secara optimal. Berdasarkan hasil temuan yang diperoleh di lapangan melalui langkah-langkah yang terdapat dalam konsep pembelajaran menggunakan model VAK berbasis Tri Kaya Parisudha yang mengoptimlkan tiga modalitas belajar yaitu melihat, mendengar dan mengerjakan. Terlihat siswa mampu mengembangkan pemikiran awalnya dengan cermat melalui pengamatan, secara tidak sadar siswa sudah mampu meningkatkan konsentrasi dan fokusnya pada materi baru yang akan dipelajarinya. Siswa terus diajak terlibat proaktif setiap waktu, terlihar siswa begitu antusias dan berambisi selama pelajaran di kelas berlangsung. Aspek yang terkandung pada model pembelajaran VAK ialah bagian yang substansial dalam menyerap berbagai informasi saat proses belajar. Setiap individu tentu memiliki gaya belajar yang berbeda-beda melalui model VAK ini siswa dilayani setiap kebutuhannya, sehingga membantu peserta didik memahami materi yang sudah dipelajajrinya dan cakap dalam membuat kesimpulan dari informasi yang diperolehnya baik dari kegiatan observasi maupun tanya jawab. Hal ini tentu menjadikan pembelajaran manjadi lebih bermakna bagi diri siswa dan memberikan dampak yang positif terhadap peningkatan kompetensi pengetahuan IPA yang dimilikinya. Temuan yang diperoleh di lapangan dengan penerapan model pembelajaran VAK sangat tepat untuk mengatasi asumsi terkait muantan materi IPA yang dianggap membosankan dan penuh dengan hapalan. Hal ini dikarenakan dalam kegiatan belajarnya siswa dilatih secara maksimal dalam mengelaborasi suatu konsepsi melalui kegiatan fisik, dari aktivitas tersebut siswa dapat membangun pemahamannya secara mandiri untuk mempermudah mempelajari materi IPA. Perpaduan ajaran Tri Kaya Parisudha dalam penelitian ini sangat mendukung kesuksesan dari model pembelajaran VAK, dikarenaan materi IPA yang cukup kompleks harus dibiasakan terlebih dahulu dengan pemikiran yang terpusat saat belajar (manacika parisudha). Saat siswa ingin bertanya, menyapaikan hasil pengamatan maupun diskusinya diajarkan untuk berbicara yang sopan dan komunikatif (wacika parisudha). Menguasai materi IPA yang padat tentu membuat siswa cepat jenuh, dengan demikian siswa harus diajak untuk melakukan sebuah percobaan-percobaan yang menarik, seperti misalkan pada saat membahas mengenai materi panas dan perpindahannya. Apabila hanya belajar secara teori saja tentu dirasa kurang, karena belajar IPA perlu suatu pembuktian, maka diperlukan sebuah eksperimen sederhana saja. Mengajak siswa secara berkelompok mengamati es batu yang ditempatkan di dalam ruangan dengan es batu diletakan di luar ruangan yang terkena matahari atau eksperimen mengenai perpindahan kalor secara konduksi dengan mengamati batang kayu, batang besi dan batang plastic yang dicelupkan ke dalam segelas air panas. Dengan adanya percobaan ini yang melibatkan modalitas kinesthetic siswa akan sangat dibantu dalam memahami materi IPA yang tidak bisa dijelaskan dengan kata-kata akan tetapi bisa dimaknai dan dimengerti dengan melakukan kegiatan fisik (kayika parisudha). Hal inilah yang membuat siswa menjadi lebih diperhatikan, prose belajar pun menjadi berharga bagi siswa dan penguasaan kompetensi pengetahuan IPAnya menjadi meningkat.

Hal berbeda terlihat pada proses pembelajaran di kelas kontrol yang dibelajarkan secara konvensional. Peserta didik kurang antusias karena minimnya kesempatan untuk mengeluarkan pendapat serta kesempatan siswa untuk bertukar pikiran pun juga terbatas. Pembelajaran berjalan kurang optimal karena, kegiatan siswa lebih banyak dilatih untuk mengerjakan soal-soal pada buku siswa saja, sehingga siswa kurang bersemangat dalam proses pembelajran. Secara garis besar pembelajaran masih di dominasi oleh guru.

Temuan hasil penelitian ini berkitan dengan teori yang menyatakan bahwa, kompetensi pengetahuan IPA bersumber dari kemampuan diri setiap siswa dan kegiatan pembelajaran. Dengan model VAK berbasis Tri Kaya Parisudha peserta didik dapat mencerna materi dengan cekatan dan dapat diingat dalam jangka waktu yang lama, karena siswa sendiri terlibat secara langsung. Model pembelajaran VAK berprinsip menciptakan situasi belajar menjadi nyaman dan menjanjikan kegemilangan bagi siswa dimasa yang akan datang (Ngalimun, 2015). Ibrahim dkk (2015) melayanin setiap keperluan modalitas belajar siswa yaitu visual, auditory, kinestetic akan membantu dalam 
menyaring materi yang hendak dipelajari dan dapat meningkatkan kerjasama antar siswa. Selain teori tersebut hasil penelitian ini relevan dengan penelitian yang dilakukan oleh Ni Pt. Emilia Pebriani (2018) bahwa ditemukan perbedaan yang signifikan prestasi belajar peserta didik yang diajarkan melalui model VAK berbantuan VCD dengan peserta didik yang diajarkan melalui pembelajaran biasa. Terlihat dai hasil uji hipotesis diperoleh $t_{\text {hitung }} \geq t_{\text {tabel }}\left(t_{\text {hitung }}=3.61>t_{\text {tabel }}=2.00\right)$ dan nilai tengah kelompok eksperimen lebih dari kelompok kontrol. Hasil penelitian ini sepaham juga dengan yang dilakukan oleh Nanik Suryantini (2018) yang menemukan bahwa penerapan model VAK dapat berpengaruh signifikan terhadap hasil belajar IPA siswa kelas V SD. Hal ini terlihat dari persentase nilai $t_{\text {hitung }} \geq t_{\text {tabelyakni sebesar }}$ $3,259 \geq 2,000$. Hal tersebut juga terbukti dalam penelitian ini, saat keadaan awal yang belum menerapkan model pembelajaran VAK pada muatan meteri IPA, hasil kompetensi pengetahuan IPA masih rendah. Kemudian saat dibelajarkan menggunakan model VAK berbasis Tri Kaya Parisudha, hasil yang didapat yakni kompetensi pengetahuan IPA siswa mengalami peningkatan

Penelitian ini memberikan implikasi terhadap pembelajaran di Sekolah Dasar. Implikasi secara teoritis penggunaan model pembelajaran yang tepat dengan kompotensi mampu membantu siswa mencapai tujuan pembelaajran, meningkatkan keatifan siswa dan pencapaian kompetensi pengetahuan siswa. Dalam pelajaran IPA, terdapat perbedaan antara kompetensi pengetahuan IPA siswa yang dibelajarkan menggunakan model pembelajaran VAK dengan siswa yang diajarkan secara konvensional. Sedangkan implikasi secara praktis dari hasil penelitian ini dijadikan pertimbangan oleh guru dalam mendisign pembelajaran yang menarik. Hal yang bisa dilakukan yakni menyiapkan dan meningkatkan kualitas diri sehubungan dengan pembelajaran yang sudah dilaksanakan dan memperhatikan pemilihan model pembelajaran yang sesuai sehingga bisa meningkatkan kompetensi pengetahuan IPA siswa menjadi lebih optimal.

Berdasarkan paparan tersebut, dapat ditarik sebuh kesimpulan bahwa model pembelajaran VAK berbasis Tri Kaya Parisudha berpengaruh secara signifikan terhadap kompetensi pengetahuan IPA Kelas V SDN Gugus VI Kecamatan Sukawati Tahun Ajran 2019/2020.

\section{SIMPULAN DAN SARAN}

Berdasarkan hasil pengujian hipotesis dan pembahasan dapat disimpulkan, model pembelajaran VAK Berbasis Tri Kaya Parisudha berpengaruh secara signifikan terhadap kompetensi pengetahuan IPA kelas V SDN Gugus VI Kecamatan Sukawati Tahun Ajaran 2019/2020. Berdasarkan hasil penelitian yang diperoleh diutarakan beberapa saran, kepada guru dapat menggunakan berbagai model pembelajaran sebagai variasi dalam mengoptimalkan hasil belajar siswa, khususnya kompetensi pengetahuan IPA dengan penerapan model pembelajaran VAK berbasis Tri Kaya Parisudha. Kepada kepala sekolah, hasil penelitian ini dijadikan pendukung kebijaksanaan kepala sekolah meningkatkan kapasitas pembelajaran dengan tercipta situasi belajar yang mengasyikkan di sekolah, sehingga sekolah melahirkan peserta didik yang berbobot dan kepada peneliti lainnya, hasil penelitian ini dapat dipergunakan sebagai literature dalam pelaksanaan penelitian berikutnya dan mengujicobakan pengaruh model ini pada muatan materi lainnya.

\section{DAFTAR PUSTAKA}

Adnyani, Widya. 2020. Pengaruh Model Pembelajaran VAK Berbasis Whole Brain Teaching Terhadap Kompetensi Pengetahuan IPA. e-Journal PGSD Universitas Pendidikan Ganesha.

Ambarawati, Mega. 2020. Efektivitas Model Pembelajaran (CIRC) Berbantuan Scramble Terhadap Kompetensi Pengetahuan. e-Journal PGSD Universitas Pendidikan Ganesha.

Arisantiani. 2018. Pengaruh Model Pembelajaran (CLIS) Childrens Learning In Science Berbantuan Media Lingkungan Terhadap Kompetensi Pengetahuan IPA. Jurnal Universitas Pendidikan Ganesha.

Atmaja, Kusuma. 2019. Pengaruh Model Pembelajaran Kooperatif Tipe Concept Song Berbasis Lagu Anak Terhadap Kompetensi Pengetahuan IPS Siswa Kelas IV SD Negeri 3 Sukawati Tahun Ajaran 2018./2019. e-Journal PGSD Universitas Pendidikan Ganesha.

Ayu. Triyana. 2020. Pengaruh Model Pembelajaran (SAVI) Berbantuan Multimedia Terhadap Kompetensi Pengetahuan IPA. e-Journal PGSD Universitas Pendidikan Ganesha.

Cantona, Eric. 2020. Model Pembelajaran SAVI Berbantuan Media Mind Mapping Meningkatkan Hasil Belajar IPA Siswa Kelas V. e-Journal Universitas Pendidikan Ganesha.

DePoter, Bobbi. 2016. Quantum Teaching. Bandung: Kaifa. 
Dewi, Eri Kumala. 2018. Pengaruh Model Pembelajaran Projek Based Learning Berbantuan Media Outdoor Terhadap Kompetensi Pengetahuan IPA Kelas V. e-Journal PGSD Universitas Pendidikan Ganesha.

Elisa, Desti. 2019. Penerapan Model Pembelajaran VAK Terhadap Hasil Belajar IPA Peserta Didik Kelas IV SD 147 Pekanbaru. Jurnal Dinamika Pendidikan Dasar Universitas Riau.

Emilia, Pebriani. 2018. Pengaruh Model Pembelajaran VAK Berbantuan Media Magic Box Terhadap Hasil Belajar IPA Kelas IV SD. E-Jurnal Universitas Pendidikan Ganesha.

Febbriana, Anditha. 2019. Pengaruh Model Pembelajaran Word Square Berbasis Outdoor Study Terhadap Kompetensi Pengetahuan IPA. e-Journal PGSD Universitas Pendidikan Ganesha.

Gosachi, Adistha. 2020. Model Pembelajaran Make A Match Berbantuan Media Kartu Gambar Meningkatkan Hasil Belajar Matematika. E-Journal Universitas Pendidikan Ganesha,

Huda. 2015. Model-Model Pengajaran dan Pembelajaran, Yogyakarta: Pustaka Pelajar

Krismayoni, Windha. 2020. Pembelajara IPA dengan Model Pembelajaran Children Learning In Science Meningkatkan Hasil Belajar Ditinjau Dari Minat Belajar. e-Journal Universitas Pendidikan Ganesha.

Lestari, Mega. 2018. Pengaruh Model Quantum Teaching Berbasis Pmaendidikan Karakter Terhadap Kompetensi Pengetahuan IPA. e-Journal PGSD Universitas Pendidikan Ganesha.

Pramita, Dewi. 2018. Pengaruh Model Pembelajaran Think Talk Write Berbantuan Mind Mapping Terhadap Kompetensi Pengetahuan IPA Kelas IV. e-Journal PGSD Universitas Pendidikan Ganesha.

Paramita. Ega. 2020. Model Discovery Learning Berbasis Outdor Study Terhadap Hasil Belajar IPA. eJournal Universitas Pendidikan Ganesha.

Putri, Dwika. 2019. Pengaruh Model Pembelajaran Discovery Learning Berbantuan Lingkungan Terhadap Kompetensi Pengetahuan IPA Siswa Kelas V. Jurnal Universitas Pendidikan Ganesha.

Primayonita. Kris. 2020. Model Creativity Learning Meningkatkan Keterampilan Berpikir Kreatif dan Tanggung Jawab Pada Mata Pelajaran IPA. e-Journal Universitas Pendidikan Ganesha.

Raharja. Gayatri. 2019. Model Pembelajaran Think Pair Share Berpengaruh Terhadap Kompetensi Pengetahuan IPA Siswa Kelas V SD. e-Journal PGSD Universitas Pendidikan Ganesha.

Rani, Megita. 2019. Pengaruh Model Pembelajaran Talking Stick Berbantuan Lagu Tradisional Terhadap Kompetensi Pengetahuan IPA. e-Journal PGSD Universitas Pendidikan Ganesha.

Rukmana, Winda. 2018. Peningkatan Aktivitas dan Hasil Belajar Dengan Model Pembelajaran VAK Berbantuan Media Tongkat Tokoh. e-Journal Universitas Pendidikan Ganesha.

Samatowa. 2016. Pembelajaran IPA di Sekolah Dasar. Jakarta. PT. Indeks

Septiawan, Dodik. 2020. Pengaruh Model Pembelajaran ARCS Terhadap Belajar IPA Siswa Kelas IV Sekolah Dasar. e-Journal Universitas Pendidikan Ganseha.

Shoimin, Aris. 2016. 68 Model Pembelajaran Inovatif dalam Kurikulum 2013. Yogyakarta: Ar-Ruzz Media Sri, Ary. 2018. Penerapan Konsep Tri Kaya Parisudha Dalam Pembelajaran Sains. Jurnal Universitas Panji Sakti.

Singer, I Wayan. 2017. Pendidikan Karakter Berlandaskan Tri Kaya Parisudha. Manikgeni

Suryantini, Nanik. 2018. Pengaruh Model Pembelajaran Visual Auditori Kinestetik Berbantuan Audio Visual Terhadap Kompetensi Pengetahuan IPA Kelas V. e-Journal Universitas Pendidikan Ganesha.

Urmila, Dewi. 2019. Pengaruh Model Pembelajaran TAI Berbantuan Media Peta Konsep Terhadap Kompetensi Pengetahuan IPS Siswa Kelas IV Sekolah Dasar. e-Journal PGSD Universitas Pendidikan Ganesha.

Variani, Devi. 2020. Model Pembelajaran Discovery Learning Berbantuan Media Mind Mapping Terhadap Hasil Belajar IPA Siswa Kelas V. Jurnal Universitas Pendidikan Ganesha.

Widiastiti. Ayu. 2020 Model Quantum Teaching Berbasis Pendidikan Karakter Terhadap Motivasi Belajar IPA Siswa Kelas IV. Jurnal Universitas Pendidikan Ganesha

Yudiana, Kadek. 2020. Model Pembelajaran STAD Berorientasi THK Meningkatkan Kompetensi Pengetahuan IPA Siswa Kelas V Sekolah Dasar. e-Journal Universitas Pendidikan Ganesha. 